\title{
Towards A Responsible Entrepreneurship Education and the Future of the Workforce
}

Paul Agu Igwe, Ugochukwu Chinonso Okolie \& Chioma Vivienne Nwokoro (2019), Towards a responsible entrepreneurship education and the future of the workforce. The International Journal of Management Education, Available online 15 May 2019

https://doi.org/10.1016/j.ijme.2019.05.001

\section{Highlights}

- PRME provides a Compass for universities to embed responsible education.

- Limited information is available on the stream of African Entrepreneurship education.

- Many universities are ill-equipped to develop adequate skills required for the modern job market.

- This study is based on the Curricular, Co-curricular and Extra-curricular Learning Pipeline Model.

\begin{abstract}
This article explores how entrepreneurship education (EE) could be adopted towards improving graduate's skills and preparing the future workforce. It adopts interviews with 30 experienced higher education academics, executives of employment and work placement agencies in Nigeria that reveals substantial benefits of adopting entrepreneurial pedagogics, critical thinking and problem-based learning (PBL). The critical question is how can EE practices be utilised in higher education to improve future workforce? Linked to the UN Principles of Responsible Management Education (PRME), this study is based on the model of curricular, co-curricular and extra-curricular learning pipeline that focuses on 'learning in the curriculum' and 'learning beyond the curriculum'. The model somehow links to the six domains that formed our analytical model - knowledge and cognitive learning, innovation in teaching pedagogy, change in thinking, change in attitudes, social learning and change in action.
\end{abstract}

Key Words: Entrepreneurship Education, Responsible Management Education, Problembased Learning, Critical Thinking, African Higher Education

\section{Introduction}

The study of entrepreneurship in higher education institutions (HEIs) is one of the more interesting and challenging areas of research for universities, governments, and industrial sectors (Kabongo \& Okpara, 2010). In line with Principles 1 and 2 of the United Nations Principles of Responsible Management Education (PRME), this article aims to identify the precise mechanisms by which EE, teaching and learning could be adopted in the higher education to facilitate the future workforce in Nigeria (a typical example of a developing world context). It explores EE implementation, practices and challenges. Such a study is timely. There is much evidence that many African universities are ill-equipped and do not always help graduate develop adequate skills to respond to the requirements of the modern job market (e.g., 
British Council Nigeria, 2010; British Council, 2014; GEM, 2015). The world community has discovered that to create jobs in countries means they must enhance the potential of entrepreneurship (Bawuah, Buame \& Hinson, 2006).

Indeed, the number and diversity of courses offered in management degrees have increased over the past two decades. However, there have been concerns about the way management education (ME), and EE takes place. Central to these concerns is that business schools fail in their responsibilities to students, delivering a narrowly focused curriculum that is over-reliant on ideas of abstract rationality, scientific rigour and value neutrality (Millar \& Price, 2018). Also, some of the criticisms of business schools are that they are failing to train graduates who can be relied upon to integrate the functions of management (e.g. Adizes, 2013; Millar \& Price, 2018).

Entrepreneurship and local private enterprise are critical components of African economic development (Brixiova, Ncube \& Bicaba, 2015; Oluwatobi et al., 2015; White, 2011). As a result, entrepreneurship agenda has been promoted by governments, universities and international agencies as one solution to reducing the high rate of unemployment (UN, 2013) and informal activities in Africa (Bawuah et al., 2006). Writing on 'ticking time bomb', the UN (2013) states that the story of Africa's worrisome youth unemployment is often told alongside the story of the continent's fast and steady economic growth. But the problem is that in most African countries, youth unemployment occurs at a rate more than twice that for adults (UN, 2013, p. 1). The problem has been exacerbated by a high rate of unemployment among university graduates in some countries (see, e.g., Álvarez-González, López-Miguens \& Caballero, 2017).

Arguably, sustainable development at all levels and in all social contexts is required to transform society by reorienting education and help people develop knowledge, skills, values and behaviours (UNESCO, 2018). Therefore, the critical question is how entrepreneurship teaching and learning methodologies could be utilised to prepare the future workforce in Africa. This has been a major concern (British Council, 2014; GEM, 2015). Many scholars call for critical thinking approach (Leong (2013), an entrepreneurial approach to ME (Ahmad, Bakar \& Ahmad, 2018; Jones et al., 2017) and PBL approach (Garnjost and Brown, 2018) to consider potential changes in management functions. Also, there is evidence that individual and groups mutually influence and transform one another during teamwork (Byrne et al., 2016).

In developing countries, such as Nigeria, the higher education predominantly adopts the traditional teaching approach which many have criticised and termed passive method of teaching (Blanton, Sindelar \& Correa, 2006; Gorghiu et al., 2015). Gorghiu et al., (2015) illustrate that the predominant traditional teaching method as passivity amid the learners who are often kept in the position of ready-made knowledge consumers. The authors further explained that in such a 'passive' learning setting, the students are considerably made to reproduce the same knowledge through examinations or evaluation texts.

Economists maintain that the major obstacle to the economic growth of developing nations is the lack of educated entrepreneurs who are able to mobilise and coordinate production inputs (Bawuah et al., 2006). Recent studies on African knowledge exchange (KE) and entrepreneurship focus on motivating three main strands (Asongu \& Tchamyou, 2016, p.102). First, the need for entrepreneurship and investment. Second, business strategies for achieving sustainable progress. Third, KE on the continent. Our study adopts a qualitative approach that enabled the assembling of data from higher education academics, students on industrial work scheme, industry experts and administrators of Directorate of employment. This helped us to advance and add to the knowledge about EE teaching pedagogics in the Nigerian HEIs. 


\section{Entrepreneurship Education and Management Education}

A comprehensive review of the EE and ME literature is beyond the scope of this article as it is vast and has received a considerable evaluation in many domains (Shook et al., 2003; Morris et al., 2013). The Vision 2030, UN PRME Principles 1 and 2 are defined as 'Purpose' and 'Values', respectively (UN, PRME, 2017). Since its development, more than 650 business schools all over the world have signed up as supporting organisations. The 'Purpose' aims to develop the capabilities of students to be future generators of sustainable value for business and society at large and to work for an inclusive and sustainable global economy. While the 'Values' aim to incorporate into academic activities, curricula, and organisational practices the values of global social responsibility (PRME, 2017).

Morris et al., (2013) suggest that education serves as a platform for transforming students into entrepreneurs. However, they hope that a more desirable outcome should be the transformation of students into successful entrepreneurs that embody essential entrepreneurial competencies. Writing on the same issue, Krecara and Coric (2013) posit that in the context of $\mathrm{EE}$, it assumes activities which allow students to gain direct experience with entrepreneurial practices through "learning by doing" experience.

\subsection{Problem-based Learning (PBL) and Knowledge Acquisition}

PBL creates a learning environment where "inquiry activities, self-directed learning, information mining, dialogue and collaborative problem-solving can be incorporated in the teaching design to enrich the student learning experience" (Stanley \& Marsden, 2012: p. 286). It also allows the students to determine what to learn by using a student-centered approach; and it assists teachers in facilitating and stimulating the students to ask questions to themselves (Barrows, 2002). PBL offers the teachers opportunity to coach or guides the students to work on identified or a specific problem to enable them to develop relevant skills and competence to be fit in the world of work (O'Grady et al., 2012).

With the introduction of the PBL, the students realize that they can develop useful skills, knowledge and attitudes to solving challenging problems that are in real life (Barrows, 2002). The PBL is planned and arranged around difficulties, which are identifiable, instead of courses or disciplines and the highlights is on integrated learning. The PBL according to Boekaerts, Pintrich \& Zeitner (2002) have the chances of motivating the students to develop answers to emerging specific problems through more in-depth or critical thinking. Such opportunities that lie in the use of PBL approach can also enhance the acquisition of entrepreneurial skills to enable higher education students to become employers of labour upon graduation.

Therefore, PBL is a significant component of entrepreneurial though \& action (ETA) - a new mental model for leadership approach. There are two forms of complementary logic underlying ETA - Prediction Logic and Creation Logic. In a book published by Babson College, Massachusetts, USA and written by Greenberg, McKone-Sweet \& Wilson (2011), they emphasise that with creation logic, students learn that the future is created, not predicted. They go on to state that in unknowable situations, action is needed to determine about the new case, to further assess the problems and opportunities, and to select the next course of action [...]. While a prediction logic assumes that certain future can be predicted and that decisions can be made based on these predictions (Greenberg et al., 2011, p. 1).

Some studies (e.g., Harrison \& Killion, 2007) suggest that a teacher must be: resource provider; instructional specialist; curriculum specialist; classroom supporter; learning facilitator; mentor; school leader; data coach; a catalyst for change; and learner. Also, teachers create a learning environment that enables students to develop competencies (Snoek \& Zogla, 2009; OECD, 2014). The mechanisms that interconnect PBL and ME are at the heart of this article. Previous research on the effectiveness of PBL focuses on the five learning outcomes 
employers have identified as expecting from business students skillsets as follows: knowledge acquisition, critical thinking, teamwork and problem solving (Garnjost \& Brown, 2018).

The model of the "knowledge acquisition" process is primarily one of epistemology or the theory of knowledge and problem solving (Alt, 2015; Ratten, 2017). There are two assumptions to the context: the first has its origin in philosophy as a "method of learning" proposed by Aristotle, and the second points to the process which takes place in knowledge-based systems (Bosancic, 2016, p. 937). According to Zins (2007), both distinguish between 'empirical knowledge' (or 'know-how' 'empeiria') and explicit knowledge (or 'know-that,' 'episteme'). Garnjost and Brown (2018) provide many examples of research on knowledge acquisition and PBL. One was in a single business course, in which a study by Carriger (2016) found that content learning and knowledge acquisition was higher in the lecture-based approach as compared to a PBL based approach when measured by course grades, exam grades or writing assignment grades. Another is work by Bamford et al. (2012) that found students in a PBL operations management class perceived a higher level of skills and knowledge from the PBL pedagogy (cited in Garnjost \& Brown, 2018).

\subsection{Critical Thinking}

In a co-publication with the British Medical Journal (BMJ) by Sharples et al., (2017, p.1) on critical thinking, they described it as encompasses a broad set of skills and dispositions, including cognitive skills (e.g. analysis, inference and self-regulation); approaches to specific questions or problems and approaches to life in general (e.g. inquisitiveness, concern with being well informed, and open-mindedness). Watanabe-Crockett (2018) emphasises that teaching critical thinking skills to students is necessary because they're crucial skills for living life. It is a key competency in most frameworks for national curricula for primary and secondary schools (Voogt \& Roblin, 2012). As such, every teacher is looking for interesting ways to integrate it into classrooms (Watanabe-Crockett, 2018).

Although multiple definitions exist, Leong (2013) maintain that many scholars agree that critical thinking is best viewed along the lines of a two-stage process as follows:

The first stage, critical reasoning, requires one to understand a text well enough to assess it. The second stage, creative logic, requires one to create a new, logically defensible version, whether oral or written, related to the original one. In short, "critical thinking means more than simply comprehending a text well enough to summarise it or agree or disagree with it. It requires ... not merely 'knowledge-telling' but 'knowledge-transforming”' (Dobson \& Feak, 2001, cited in Leong 2013, p.576).

Canziani and Tullar (2017, p. 272) emphasise that "information literacy is a large component of critical thinking-to think critically, a student needs to be able to gather and assess information. But what exactly are critical thinking skills and what are some of the best strategies? This involves the ' $5 \mathrm{Ws}$ ' analysis as presented in Figure 1 framework. Critical thinking is the attempt to ask and answer questions systematically in a most productive sequence. Developed by the Learning Development, Plymouth University (2010), crucial questions that need to be asked for almost any topic are: 'what', which identifies the issue; 'why', which explores it in depth, addressing causes and using theory; 'how', which helps you look at the processes at work; and 'so what', which helps you make conclusions, showing that you have reflected on the implications. 


\section{Figure 1}

Critical Thinking Framework

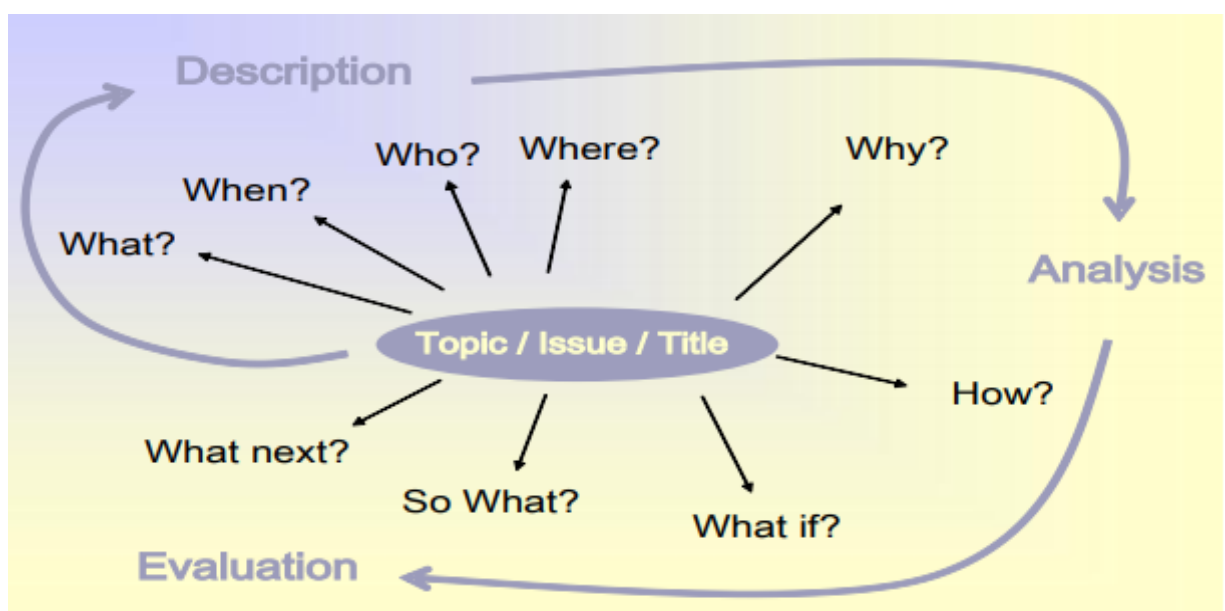

Source: Hilsdon (2010, p.2) Learning Development, Plymouth University.

\subsection{Teamwork and Self-directed Learning}

Teamwork has been conceptualised within several theoretical models (McEwan et al., 2017). Within teams, members' behaviours can be categorized regarding both 'task work' and 'teamwork' processes (McEwan et al., 2017). The earlier represents what it is that teams are doing, whereas the latter describes how they are doing it with each other (Marks, Mathieu \& Zaccaro, 2001). Indeed, for learning to take place, individuals must be motivated to learn. It is through an understanding of their interface with other counterparts that learners can change their actions (Swart and Harcup, 2012). Teamwork is associated with self-regulated learning;

Self-regulated learning is an active, constructive process whereby learners set goals for their learning and monitor, regulate, and control their cognition, motivation, and behaviour, guided and constrained by their goals and the contextual features of the environment (Nicol and Macfarlane-Dick, 2006, p. 202).

The capacity to think critically is, like a lot of learning, developed in school and the home. Parental influence creates an advantage for students who live in homes where they are encouraged to think and talk about what they are doing, which, importantly, goes beyond simply completing tasks to creating a deeper understanding of learning processes (Sharples et al., 2017) and solving problems.

\section{Summary of the Literature}

The literature review on the effectiveness of PBL regarding the five skillsets as intended learning outcomes reveals a mixed result. However, each element of the model point to the process of developing the students' entrepreneurial intentionality and facilitate the ability of the students to master the act of business start-up, which is learning to do (Pittaway \& Cope, 2007; Nabi, Holden \& Walmsley, 2010). EE has grown speedily in the HEIs globally (Greene \& Saridakis, 2008; Fretschner \& Weber, 2013) and the growth has been determined by the promise of the entrepreneurship to be a medium for promoting economic growth and renewal globally.

This study, therefore, examines how the combination of these elements can facilitate the future workforce. The QQA (2018) provide a distinction between the study of the topic of 
learning 'about' and learning 'how to do or be' (learning 'for') which we have adopted for this study. The earlier focuses on courses that are intended to help students to assimilate and reflect upon existing knowledge and resources that enhance their understanding of a topic, for example, venture creation and business growth strategies.

The latter focuses on courses designed towards creating enterprising mindsets in graduates and helping learners to discover what it is to be enterprising, as well as offering insights into being an entrepreneur. Both have been described in the two forms of learning - "learning in the curriculum" and "learning beyond the curriculum" (as shown Figure 2) that shows typical student's journey (shown in the boxes as examples) to illustrate a potential pipeline of activities. These activities are typically delivered via experiential learning that engages and enhances the student's abilities and skills.

\section{Figure 2}

The Curricular, Co-curricular and Extracurricular Learning Pipeline Model.

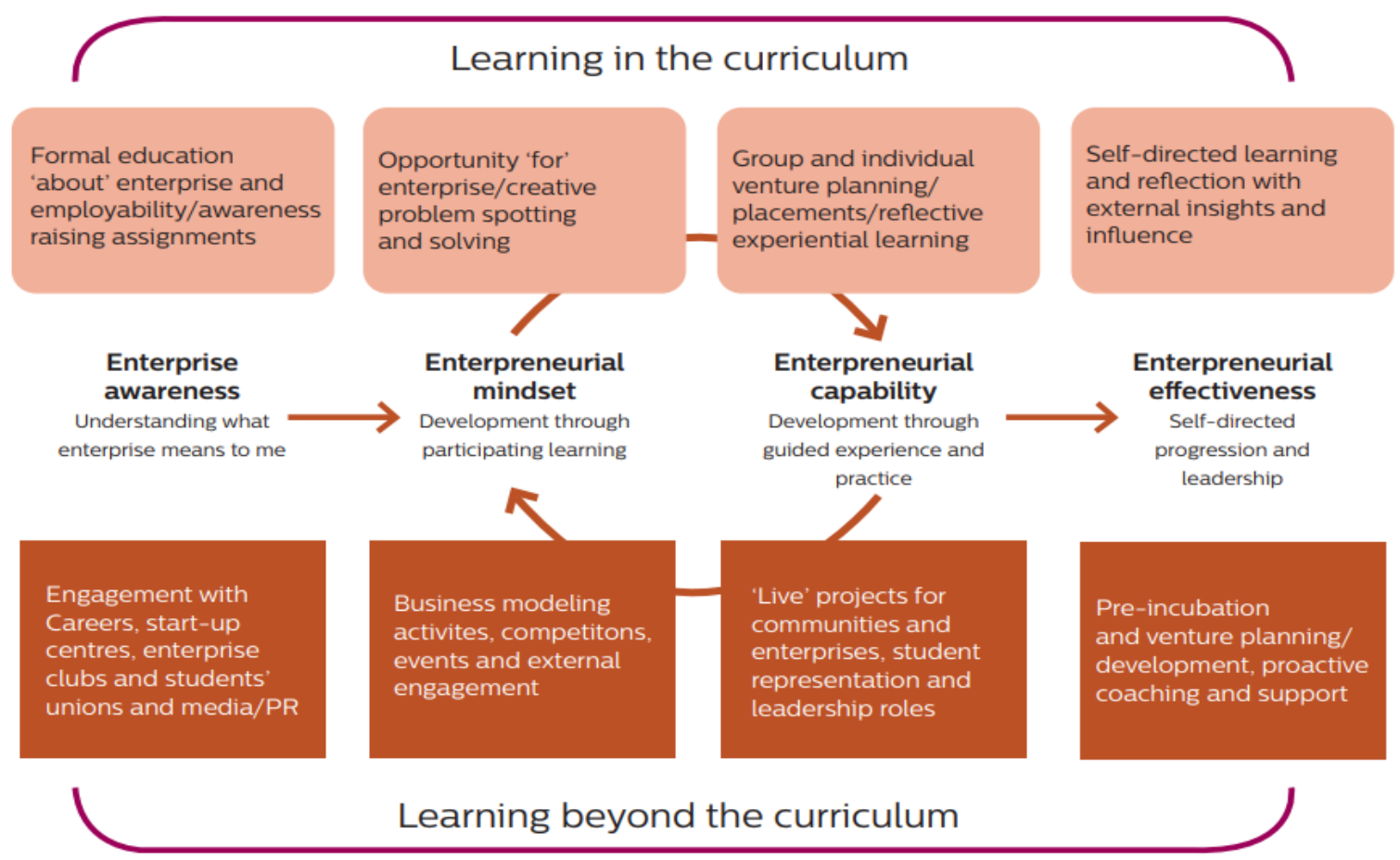

Source: QAA (2018, p.22).

\section{Research Questions}

Sustainable education development entails the development of technology with valueadded services; enhancement of existing practices; providing conditions that are essential for competitiveness; and adjustment to globalization challenges (Asongu \& Tchamyou, 2016, p.103). This research focuses on the Nigerian Higher education system, providing an avenue to explore EE and how it is linked to educational processes and workforce development. Based on the objectives of the study and the literature reviewed, the study formulates the following research questions:

RQ1: How can entrepreneurial education, teaching and learning methodologies be utilised in higher education? 
RQ2: How can the future workforce be facilitated through entrepreneurial actions and PBL approaches in higher education?

\section{Methodology, Data collection and Analysis}

This study adopted the qualitative research method to allow an in-depth opinion of the study participants on the subject under investigation. Ary, Jacobs \& Sorenson (2010) noted that the qualitative research method enables the capture of a rich and comprehensive image of a situation and allow the participants to share their views about their experiences in detail (Denzin \& Lincoln, 2005). We collected data using a semi-structured interview approach (Wengraf, 2001). The procedure for the arrangement of the interviews took the following stages. First, we called for voluntary participants through email invitation letters to higher education experts, whom we harnessed their email contacts from the websites of 10 Nigerian public and private Universities, the brochures of the National Directorate of Employment (NDE), the annual booklet of top Nigerian Industry executives and the brochure of the Industrial Training Fund, responsible for the higher education student's placements.

The invitation messages stated the aim of the research and a request for interested participants to contact the researcher. In the invitations, we also asked for a short biography (qualifications, positions and years of experiences) of those volunteering to take part in the research. We sent a reminder for eight weeks. This process generated a reasonable response rate of interest to participate in the study of 62 respondents. Second, we analyzed the short biography of the 62 responses (purposeful sampling) to identify those with exceptional knowledge of the main subject under inquiry. The logic and benefits of 'purposeful sampling' techniques for primary research have been well explained by Patton (2002, p. 230) who described it as the process of selecting information-rich cases. Hence, through purposeful sampling, we identified 30 respondents which we interviewed (presented in Table 1).

Table 1

Description of participants and their corresponding codes

\begin{tabular}{|c|c|c|c|}
\hline $\begin{array}{l}\text { Participants } \\
\text { Codes }\end{array}$ & $\begin{array}{l}\text { Number of } \\
\text { interviewees }\end{array}$ & Descriptions of the interviewees & $\begin{array}{l}\text { Years of } \\
\text { Experience }\end{array}$ \\
\hline MEA/NU & 9 & $\begin{array}{l}\text { Management and Entrepreneurship academics } \\
\text { - Nigerian Universities }\end{array}$ & $5-10$ \\
\hline $\mathrm{EO} / \mathrm{NDE}$ & 5 & $\begin{array}{l}\text { Executive Officers of the National Directorate } \\
\text { of Employment }\end{array}$ & $8-14$ \\
\hline IE/UP & 4 & $\begin{array}{l}\text { Industry executives linked to university } \\
\text { partnerships }\end{array}$ & $10-15$ \\
\hline E/IWE & 5 & $\begin{array}{l}\text { Experts of the Students Industrial Work } \\
\text { Placement Scheme (SIWES)/ Industrial } \\
\text { Training Fund }\end{array}$ & $5-10$ \\
\hline UG/IWP & 7 & Undergraduate on Industrial Work Placement & Students \\
\hline
\end{tabular}

We adopted face-to-face, telephone and Skype interviews in order to reach participants in many locations in Nigeria. The interviews followed a similar pattern and the same semistructured questions. The interviews lasted between 60 to 120 minutes (with an average for the study of 85 minutes). All the conversations were recorded and transcribed. Researchers apply 
two primary methods of transcription: naturalised transcription and denaturalised transcription (Davidson, 2009) and we adopted the naturalised transcription. In the case of naturalised transcription, the transcriber may wrongly interpret the voices heard in the recording and in so doing influence the conclusions of the research (Mero-Jaffe, 2011). To mitigate the limitation, we transferred the transcripts to the interviewees to validate if what we capture represented an accurate account of their responses. The validation was intended to confirm the transcripts, to preserve research ethics, and to empower the interviewees by allowing them to verify their statements (Mero-Jaffe, 2011; Hall 2004).

Of the 30 transcripts sent to the interviewees only 19 persons responded by confirming the scripts. Mero-Jaffe, (2011) and Hall (2004) admitted that not all the interviewees in their research responded to the transcripts. The analysis took in the form of thematic analysis employed to identify and explore themes and categories, trying to ascertain the best fit for the relationship under study (Guest, MacQueen \& Namey 2012). The method describes several different strategies for segmenting text for analysis and the relationship between segmenting and coding (Igwe et al., 2018).

\section{Findings and Themes from Qualitative Data}

Previous studies revealed that the higher education institutions in the developing countries, especially Nigeria do not adequately facilitate the future workforce thereby producing incompetent graduates (Gorghiu et al., 2015; Kincheloe, 2005) who lack necessary skills for work (GEM, 2015). Also, there are many challenges to high education in developing nations such as underfunding, inadequate facilities, the inadequacy of teaching and learning resources (e.g. Ikoya and Onoyase 2008; Okolie, Igwe \& Elom, 2018). Given this context, we set out to examine PBL and entrepreneurial approaches in teaching and learning practices and how the future workforce could be facilitated through PBL and other management learning approaches. The thematic analysis which we adopted facilitated the identification of the critical themes and categories which formed the basis of our study and discussion as the process of entrepreneurial teaching approaches model which include six domains - knowledge and cognitive learning, innovation in teaching pedagogy, change in thinking, change in attitudes of teachers \& learners, social learning and change in action (analytical model, Figure 3).

\section{Figure 3}

The model for entrepreneurial learning pedagogy

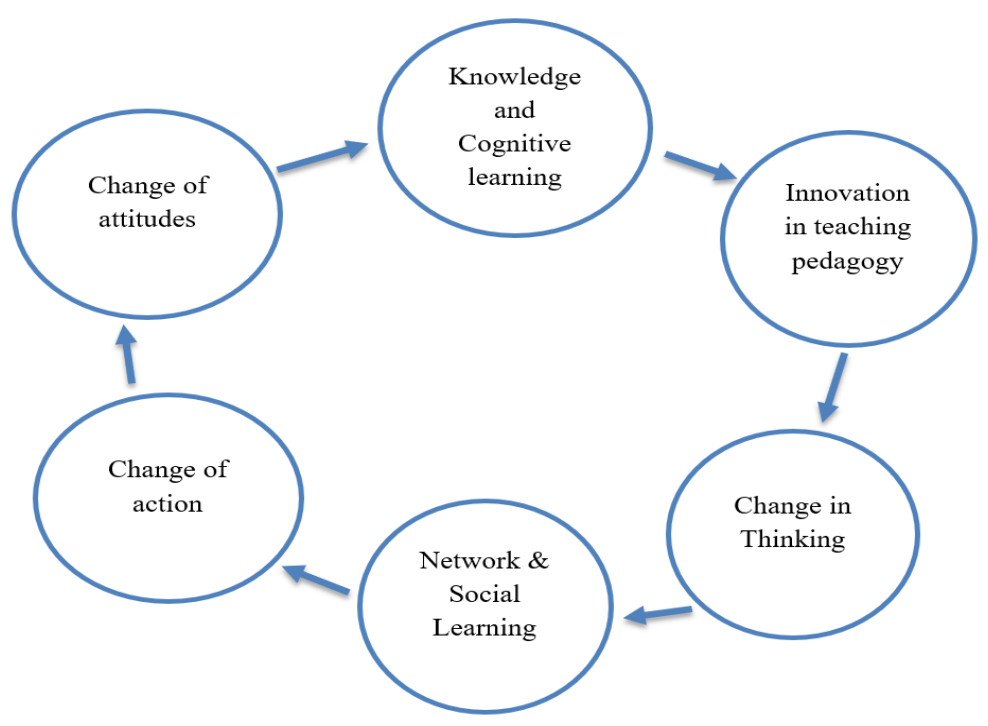




\subsection{Knowledge and Cognitive learning}

Most of the views were that the business schools in the Nigerian high education were failing to teach students to be entrepreneurial in their behaviour and affects the graduates and the future workforce. UN PRME Principles, 1 emphasises of the need to develop capabilities of students to be future generators of sustainable value for business and society. Many lamented that even after more than ten years of implementation of entrepreneurship education in the Nigerian universities, many universities still did not understand what the concept is all about not to talk about effectively teaching it. Majority of the interviewees indicated that teachers fail because most of them lack the knowledge and competencies to create an environment that allows students to explore and find opportunities rather than being able to study theory and predict the outcome to every problem;

[...] business schools fail because many of the Head of the Departments of entrepreneurship centres do not have the academic knowledge, experience in business and entrepreneurship pedagogy to achieve significant results and impact (IE/UP-01).

The overriding views were that $\mathrm{EE}$ is still seen as the part of business studies and educators often use business terminology and methods such the ones adopted in teaching general management courses like business studies, economics, etc. This is one significant problem when talking about entrepreneurial pedagogy (Gustafsson-Pesonen \& Remes, 2012). The teacher's role in imparting knowledge and cognitive learning in the students requires that the teacher is familiar with the learning process of entrepreneurship. Indeed, empirical and explicit expertise were revealed as being important in management learning (In line with studies such as Zins, 2007). Our findings indicate that this is the central problem teaching entrepreneurship in the Nigerian HEIs;

They are offering entrepreneurship because it soon became a popular programme around the world. Nothing wrong with that but they teach it as if they are teaching Economics degree. Most of the teachers have no clue what entrepreneurship education is? They only adopt the traditional teacher-student lectures style [...] (EO/NDE-03).

The above statement reflects on entrepreneurial teaching and learning pedagogies being adopted in the Nigerian HEIs. The approach needs to change. As revealed earlier, EE should focus on aspects of learning to do (Pittaway \& Cope, 2007; Nabi, Holden \& Walmsley, 2010), instead of only learning to know. The QQA (2018) suggest that EE should focus on 'how to do or be' (learning 'for'), as presented in Figure 2 and on teamwork actions (Swart \& Harcup, 2012). EE should focus on opportunity recognition and actions through methods that adopt PBL. Boekaerts, Pintrich and Zeitner (2002) maintain that PBL has the chances of motivating the students to develop answers to emerging specific problems through more in-depth or critical thinking. This will enable learners to acquire necessary skills leading to starting a trade or creating a business venture (Pittaway \& Cope, 2007).

To reduce the rate of youth unemployment and prepare students for future work, some called for revalidation of entrepreneurship programmes in the HEIs. Others advocate for transparency and competitiveness in the recruitment process and implementation of continuous professional development (CPD) programmes that would require training of all the trainers. To achieve these targets, some call for finding ways to eliminate some of the challenges such as corruption in the system, ethnicity and godfatherism. In line with previous studies in Nigeria, e.g. Ajibade-Adisa et al., (2017) the issues of Federal Character Principle and the Quota System policy, favouritism, ethnicity, age and gender discrimination, as well as corruption significantly compromise the recruitment and selection process of university staff in Nigeria. 


\subsection{Innovation in Teaching Pedagogy}

In order to achieve our research objectives, our study explored suggestions for best practices in entrepreneurship teaching methods, issues and challenges. Our findings show that the conception of EE adopted in many Nigerian universities does not teach student ways of thinking, reflecting and acting entrepreneurially. Some point to the shallow information content of the EE, lack of digital library and virtual spaces (like digital backboard). Some laments on the teaching methods where students are subjected to listening as participants rather than active interactive learning. Others point to the teaching methods that discourages entrepreneurial pedagogy such as active learning, experiential learning, teamwork and learning by doing;

[...] the share number of students that they admit to entrepreneurship and management degrees in the universities discourages innovation in teaching. How can one or two teachers possibly teach 100-200 students creativity, practice learning or organise teamwork [...]. They go with the more comfortable option that is lecturing (MEA/NU).

The experts from the industrial placement that took part in this study advocated for teaching pedagogy that allows students to gain direct experience with entrepreneurial practices through "learning by doing" experience. Best teaching pedagogy happens when the learner is at the centre of his or her learning process and carries the process holistically from the very beginning (finding the problems to solve or projects to run) to the ultimately responsible product-making (Gustafsson-Pesonen and Remes, 2012);

[...] as long as there is over-dependence on the traditional method of teaching which do not offer the students opportunities to construct learning on their own, the idea of facilitating the future workforce will remain a joke (MEA/NU-02).

\subsection{Change in Thinking}

The traditional methods of learning, which makes the teacher to be the knowledge transferor, often follow the lengthy procedure where learners are informed what they need to know, they memorize it and examples are provided to illustrate how to use it in the form of a case study. This method majority of the study participants noted, do not offer the students the opportunity to develop skills to be able to identify problems on their own without the assistance of the teacher. They emphasise that this problem is responsible for the kind of university graduates who are unable to think entrepreneurially and as such are unfit in the workplace.

[...] the only thinking they make us do is to read volumes of theories, texts and think how to apply it to pass the examination and get the best grades (UG/IWP-04).

To reduce unemployment or prepare students for work, some suggested that there is a need for a new fundamental way of thinking that involves a problem-based approach (thinking out of the box) and "learning how to do". These take the process of 'critical thinking' and 'problemsolving' (i.e. problem-based learning). Critical thinking is the attempt to ask and answer questions systematically in a most productive sequence. Learning Development, Plymouth University (2010) states that it is about exploring all possible questions with '5Ws' that helps learners to make judgements and reflected on the implications;

$[\ldots$.$] think that the PBL and entrepreneurship education (EE) are related in some way-$ while the PBL concerns with the identification and solving of problems, the EE concerns with the identification of the issues and opportunities. Both are innovation that should be encouraged as methods of teaching in the universities (EO/NDE-03). 
Another finding was on the need to encourage students to not only think about setting up profit-oriented businesses but also to think about not-for-profit and socially oriented activities. Again, this links to the UN PRME Principle 1, that relate to ways by which students can be future generators of sustainable value for business and society. Social entrepreneurs are more interested in understanding the social, economic, political, and cultural context of the problems they are trying to solve and they can be more analytical (Simons, 2013). Our findings identified some measures which will encourage social entrepreneurship. For example, activities that encourage students to design and implement a socially beneficial project for their local community. Such projects will allow students to observe and reflect on the process of planning, coordinating, evaluating, making decisions and implementing the result with the supervision of an entrepreneur or mentor.

\subsection{Network and Social learning}

Our findings indicate that students are not provided with opportunities to learn in small groups or embark on group assignments, networking, collaborative learning and cross-cultural collaborations. Very often, the activities focus on individual ability, knowledge and expertise. Many of the respondents believe this approach hinders collaborative learning and encourages individualism which does not take place in the workplace;

[...] wonder how social interaction takes place in such large class environment. The critical teaching method should focus on seminars with small groups and group assignment to allow communications, brainstorming and creativity. That is how organisations function (E/IWE-05).

To be entrepreneurial students need to learn how to organise everyday life and work within uncertainties. It is understood that "such learning needs to occur in situations that foster reimagining and re-enacting of the ways to organise the socialities of the learning process" (Butcher, 2018, p. 327). Some of the interviewees suggested the introduction of programmes and activities that are interdisciplinary. That is courses that allow multidisciplinary working across different disciplines as much as possible (e.g. projects that would enable for instance a business student to work with an engineering student);

A [...] new way of learning should be interdisciplinary. By this, I mean programmes and projects where students from different subject backgrounds work together to learn but also know about each other (E/IWE-02).

Indeed, team or group work encourages creativity and interdisciplinary knowledge, leadership, division of labour and expertise. Nigerian universities have a large number of students enrolled in the EE and ME courses that make it difficult for group activities, small group learning according to our findings. Nicol and Macfarlane-Dick (2006: p. 202) described 'small group learning' as "self-regulated learning involving active, a constructive process whereby learners set goals for their education and monitor, regulate, and control their cognition, motivation, and behaviour".

\subsection{Change in Action}

EE aim is to create future leaders who create great economic and social value-everywhere (in line with UN PRME Principle 2: 'Values'). This is the main problem in developing countries such as Nigeria and why graduate unemployment has been on the rise. Our findings indicate that a change in action by the universities and government is required. Some of our respondents emphasise that the university need to take some steps in enforcing "prediction 
logic' and 'creation logic' as the dominant teaching paradigm. They state that a new method of teaching should allow students to think, explore historical data, evaluate options and develop ideas. Some of the interviewees advocated for a new teaching method that would enable design thinking and reflective practices;

The most important aspect of this approach is that the students will be made to integrate reflective learning and self-direct learning. This approach will ensure that the students acquire specific skill based on their interests and motivation (NE/NTS-05).

UN PRME Principle 2 emphasises on the development of academic activities, curricula, and organisational practices on the values of global social responsibility. In EE and ME, students are taught to become future management leaders. To be leaders, they need to develop an approach to critical reflection and problem-solving. As noted by Greenberg, McKone-Sweet and Wilson, (2011) to successfully lead in both uncertain and unknowable situations, we need leaders who rely upon a fundamentally different rationale for the existence of business and are leveraging a different logic of business decision making.

Others maintain that government, industry and labour unions have a role to play if EE is to improve the future workforce. The role of the government include the provision of adequate funding but also to initiate schemes that encourage business competition and small business loans for students who have business ideas. Some advocate for industry-university partnership (in line with previous studies on a business model for collaboration between universities and industrial partners (Ivascu, Cirjaliu and Draghici, 2016). Here are some excerpts from a university professor;

[...] partnership is the key to active EE. The universities need to find a way to bring together key stakeholders to leverage their resources (MEA/NU-06).

The benefits of the partnership include substantial streams of external funding, enhanced opportunities for academics to work on ground-breaking research with the industries and finding solutions for pressing global challenges (Edmondson, 2012). Some believe that partnership will help to build practical knowledge among students. Others suggested activities such as students' field trips, industry visits and guest lectures and short-term or part-time work will enable students to develop practical knowledge required for work experience.

\subsection{Change in Attitude}

Our findings indicate that the attitudes of teachers and students are often seen to be the biggest obstacle to learning. In line with previous studies, e.g. (Gustafsson-Pesonen and Remes, 2012). Implementation of EE in the HEIs strictly depends on the teachers' competencies and their ability to motivate students. Some of the participants argued that many universities fail in their role to facilitate knowledge and skills because there is the absence of coaching, mentoring and career advice and counselling services. All the interviewees from the Students Industrial Work Placement Scheme raised this argument. Here is an excerpt from one of the participants; [...] will be very frank with you.... there is no coaching and guidance in the Nigerian universities. If we are serious about facilitating the future workforce, the business faculties should consider having functioning coaching, career guidance and counselling units (MT/DVR-04).

Our findings reveal that the attitudes and orientation of teachers and learners fall short of the standard. Some think university teachers are not motivated in their jobs due to the poor working conditions. Others point to low salaries compared to universities in developed economies and even lack incentives such as continuous professional development. This attitude 
is transferred to learners since there is lack of motivation and inspiration to do something creative;

[...] my long years of experience, I believe that students are more motivated when the instructor display right attitude, competent knowledge of the subject and enthusiastic about the subject (MEA/NU-04).

Some of the interviewees recall the cheating that takes place in the university which discourages and demotivates learners. They cited issues such as some academics colluding with students, friends, parents and relations to cheat by awarding underserving grades to students. Even though a learning goal orientation is often regarded as a relatively stable personality characteristic, to a certain extent, it is also susceptible to manipulation and change (Maurer et al. 2003). Therefore, many of the respondents emphasised that the starting point must be in a shift in the attitude of the teachers and learners;

[...] no doubt that standards in our education system are on a continuous slide. The grading system is fraught with manipulations. For example, much of the grading at our university has no moderation and evaluation process. What we see in so many Departments is that teachers most often award unmerited grades based on several other considerations like a personal relationship with the student (MEA/NU-01).

Teaching skills at university is a way of ensuring that HEIs fulfil their role in 'providing students with education and preparing skilled employees whose work contributes to maintaining the economy (Canton, Govan \& Zahn 2018). Our findings indicate that the teacher is the most important element in the learning process. Our study put forward some suggestions that teachers need to improve to inspire and motivate students such as awareness about the subject area and about what to do. Others include the ability to use technologies to teach, the ability to maintain transparency, act rightly, knowledge of the different needs of learners and proficiency in the use of social media.

\section{Discussion}

Our findings reveal that $\mathrm{EE}$ and $\mathrm{ME}$ mechanism involves many elements including the ones identified, analysed and evaluated in this study which include knowledge and cognitive learning, innovation in teaching pedagogy, change of thinking, change of attitudes of teachers $\&$ learners, social learning and change of action (that formed the basis of the research analytical model presented as Figure 3). Linked to the UN PRME Principles 1 and 2, this study has identified several mechanisms that will lead to knowledge exchange, responsible education, reducing unemployment and preparing the future workforce.

One of the mechanisms that we identified was enacting new behaviours (i.e. learning by doing, role modelling and collaborative learning). The thinking and actions of the teachers are vital in line with previous studies. It has been stated that "teachers learn as students learn and students learn as teachers learn" (Wallace \& Loughran, 2012, p.295). Therefore, successful EE will take place when teachers transfer their initial knowledge base to the learners by being proactive, enthusiastic and inspiring.

This is the reason why many scholars advocate that for teachers' reflection on his/her learning (National Research Council, 2010) and do critical thinking about teaching methodologies (Rebmann et al., 2015). The method of teaching should be ones that allow the students to play an active role in the learning process, ask questions (as shown in Figure 1) and to be accountable for their learning and find support (Garnjost \& Brown 2018). Also, it is important that universities into account the rapidly changing nature of technology.

Our study provides some suggestions that teachers need to improve to inspire and motivate students to increase the knowledge (know-how), skills (how to do), self-efficacy (effectiveness) 
and qualities (technical and creative knowledge) required for work or to think entrepreneurially. Group work and small group learning are vital to EE as we found. Previous research on the interconnection between individual and organisational learning assumes that knowledge begins with an individual and this learning is then embedded at the collective level (Swart \& Harcup, 2012).

The significant actions lie in the teacher's knowledge, awareness, attitude, orientations and actions. According to Dwyer (2001), the quality of teaching is highly enhanced when the curriculum is well implemented according to the expectations of learners. Besides, teachers should encourage in their teaching plan, activities that enable learners to think creatively to solve a problem, cross-disciplinary or cross-cultural learning, social network and social entrepreneurship. Also, coaching, mentoring and career counselling (e.g. Christie 2016) was proposed as an essential element that enables learners to understand their professional competencies and career choices.

\section{Conclusion, Contributions and Implications}

The United Nations (2017) reveal that youth account for $60 \%$ of all African unemployed. This is worrisome and requires innovative solutions which EE could be one solution to solving the crisis. Our findings suggest effective university-industry partnership can help the universities leverage on the key stakeholder's resources and allow industry experts to lend their knowledge and experiences to the students, teachers and researchers. Sustainable development relationships from a plethora of business fields have been documented (Rugimbana, 2010) and provide interesting strategies for thinking about the future.

As its main contribution, our article pinpoints some useful proposal about a new model of thinking linked to UN PRME Principles 1 and 2. EE focuses on engaging a decision-making logic, critical thinking, effective actions (such as the introduction of problem-based learning pedagogics) and team working. We hope that this article will contribute to better practices of EE by emphasising the elements the curricular, co-curricular and extracurricular learning pipeline model (QAA, 2018) (presented as Figure 2). These approaches we believe could vigorously strengthen the ways EE is undertaken in developing World (such as Nigeria) and thereby reduce the skills mismatch and the high rate of unemployment among university graduates (see, e.g. British Council, Nigeria, 2010; GEM, 2015).

Finally, despite the robust methods that we have adopted that enabled the identification of respondents with crucial knowledge in the subject of inquiry, the qualitative approach and validation process, there are some limitations to our research. Limiting the number of interviewees to 30 could have a potential problem with its scope. Also, the use of a structured questionnaire with close-ended questions make some crucial issues omitted or not thoroughly investigated. Despite these limitations, this our pioneering study provides a unique opportunity to advance research in the six domains that formed our research analytical model - knowledge and cognitive learning, innovation in teaching pedagogy, the change of thinking, change of attitudes, network \& social learning, and change of action. Hence, we encourage other scholars to carry out similar research in other countries of the developing world.

\section{Appreciation:}

Our Thanks goes to members of UNESCO Chair on Responsible Foresight for Sustainable Development at Lincoln International Business School (LIBS), University of Lincoln, for their support and advice. 


\section{References}

Adizes, K. I. (2013). Contemporary General Management Education: A Critique. Delivered at the meeting of the International Academy of Management, Atlanta, Georgia, USA. Accessed: 27/09/2017. http://www.ichakadizes.com/contemporarygeneral-management-education-a-critique/

Ahmad, S., Bakar, A., \& Ahmad, N. (2018). An evaluation of teaching methods of entrepreneurship in hospitality and tourism programs. The International Journal of Management Education, 16(1), 14-25.

Ajibade-Adisa, T., Osabutey, E. L.C., Gbadamosi, G., \& Mordi, C. (2017). The challenges of employee resourcing: the perceptions of managers in Nigeria, Career Development International, 22(6), 703-723

Alt, D. (2015). Assessing the contribution of a constructivist learning environment to academic self-efficacy in higher education. Learning Environments Research, 18: 47-67. doi:10.1007/s10984-015-9174-5

Álvarez-González, P., López-Miguens, M. J., \& Caballero, G. (2017). Perceived employability in university students: developing an integrated model. Career Development International, 22(3), 280-299,

Asongu, S. A. \& Tchamyou, V. S. (2016). The impact of entrepreneurship on knowledge economy in Africa. J. of Entrepreneurship in Emerging Economies, 8(1), 101-131

Ary, D., Jacobs, L. C., \& Sorenson, C. (2010). Introduction to Research in Education. New York: Wadsworth Cengage Learning. The USA.

Bamford, D., Karjalainen, K., \& Jenavs, E. (2012). An evaluation of problem-based assessment in teaching Operations management. International Journal of Operations \& Production Management, 32(12), 1493-1514

Barrows, H., (2002). Is it truly possible to have such a thing as PBL? Distance Educational, 23(1), 119-122.

Bawuah, K., Buame, S. \& Hinson, R. (2006) Reflections on Entrepreneurship Education in African Tertiary Institutions. Accessed: 02/05/2018 file:///C:/Users/Surfbook/Downloads/78-156-1-SM.pdf page 1 -9

Blanton, L. P., Sindelar, P. T., \& Correa, V. I. (2006). Models and measures of beginning teacher quality. The Journal of Special Education, 40: 115-127. http://dx.doi.org/10.1177/00224669060400020201

Bosancic, B. (2016). Information in the knowledge acquisition process. Journal of Documentation, 72(5), 930-960 https://doi.org/10.1108/JD-10-2015-0122

Boekaerts, M., Pintrich, P. \& Zeitner, M. (2000). Handbook of self-regulation. San Diego, CA: Academic Press.

Bonnie Canziani \& William L. Tullar (2017). Developing critical thinking through student consulting projects. Journal of Education for Business, 92(6), 271-279

British Council (2014). "Can higher education solve Africa's job crisis?” Understanding graduate employability in Sub-Saharan Africa. Going Global 2014. Accessed: 12/04/2018 www.britishcouncil.org/education/ihe

British Council Nigeria (2010). Next Generation Nigeria Task Force. Accessed: 12/4/18 https://www.britishcouncil.org/sites/default/files/nigeria_the_next_generation_report.pdf

Brixiova, Z., Ncube, M. and Bicaba, Z. (2015). Skills and youth entrepreneurship in Africa: analysis of with evidence from Swaziland. World Development, 67: 11-26.

Butcher, T. (2018). Learning everyday entrepreneurial practices through coworking. Management Learning, 49(3), 327-345

Byrne, J., Delmar, F., Fayolle, A., \& Lamine, W. (2016). Training Corporate Entrepreneurs: An Action Learning Approach. Small Business Economics, 47(2), 479-506 
Canton, U., Govan, M., \& Zahn, D. (2018). Rethinking academic literacies. A conceptual development based on teaching practice. Teaching in Higher Education, 23(6), 668-684

Canziani, B., \& Tullar, W. L. (2017). Developing Critical Thinking through Student Consulting Projects. Journal of Education for Business, 92(6), 271-279

Carriger, M. S. (2016). What is the best way to develop new Managers? Problem-Based learning vs. Lecture-Based instruction. International Journal of Management in Education, 14(2), 92-101.

Christie, F. (2016). Careers guidance and social mobility in UK higher education: practitioner perspectives. British Journal of Guidance \& Counselling, 44(1), 72-85

Davidson, C. (2009). Transcription: Imperatives for qualitative research. International Journal of Qualitative Methods, 8(2), 35-52.

Denzin, N. K., \& Lincoln, Y. S. (2005). Collecting and Interpreting Qualitative Materials. Thousand Oaks, CA: SAGE Publications USA.

Dobson, B., \& Feak, C. (2001). A cognitive xxx non-native approach to teaching critique writing to non-native speakers. In Leong, P. V. (2013) Thinking critically: a look at students' critiques of a research article, Higher Education Research \& Development, 32(4), 575-589

Dwyer, C. (2001). Linking research and teaching: A student interview project. Journal of Geography in Higher Education, 25: 357-366.

Edmondson, G. (2012). Making industry-university partnerships work lessons from successful collaborations. A report commissioned by the Science \&Business Innovation Board AISBL. Accessed: 05/07/2018 https://www.sciencebusiness.net/sites/default/files/archive/Assets/94fe6d15-54324cf9-a656-633248e63541.pdf

Fretschner, M., \& Weber, S. (2013). Measuring and Understanding the Effects of Entrepreneurial Awareness Education. Journal of Small Business Management, 51(3), 410-28.

Garnjost, P., \& Brown, S.M. (2018). Undergraduate business students' perceptions of learning outcomes in problem-based and faculty-centered courses. The International Journal of Management Education 16: 121-130

Global Entrepreneurship Monitor (GEM, 2015). Supporting Africa's young entrepreneurs: an investment in job creation and future prosperity for all: Nigeria. (Accessed: 20.12.2017). https://file:///F:/GEM\%202015-youth-reportsummariesNigeria-1434104122.pdf

Gorghiu, G., Drăghicescu, L. M., Cristea, S., Petrescu, M., \& Gorghiu, L., M. (2015). Problem-based learning - An efficient learning strategy in the science lessons context. Procedia - Social and Behavioral Sciences, 191:1865 - 1870

Greenberg, D., McKone-Sweet, K., \& Wilson, H. J. (2011). Babson book: The New Entrepreneurial Leader: Developing Leaders Who Shape Social and Economic Opportunity. Berrett-Koehler Publishers. Accessed: 12/06/2018, Available at: http://www.babson.edu/executive-education/thoughtleadership/entrepreneurship/Pages/entrepreneurial-thought-action-methodologydeveloping-entrepreneurial-leaders.aspx

Greene, F. J., \& Saridakis, G. (2008). The Role of Higher Education Skills and Support in Graduate Self-Employment. Studies in Higher Education, 33(6), 653-72.

Guest, G., MacQueen, K. and Namey, E. (2012). Applied Thematic Analysis. London: Sage Publication. The United Kingdom.

Gustafsson-Pesonen, A., \& Remes, L. (2012). Evaluation of entrepreneurial development coaching: changing the Teachers' thinking and action on 
entrepreneurship. Annals of Innovation \& Entrepreneurship, 3(17211), 1-12 DOI: 10.3402/aie.v3i0.17211

Hilsdon J. (2010). Learning Development, Plymouth University in collaborative partnership with Learn Higher and sixteen HEIs. Accessed: 12/04/2017 https://www.plymouth.ac.uk/uploads/production/document/path/1/1710/Critical Thinking.pdf

Hall, R.A. (2004). Inside out: Some notes on carrying out feminist research in crosscultural interviews with South Asian women immigration applicants. International Journal of Social Research Methodology, 7: 127 - 141.

Harrison, C., \& Killion, J. (2007). Ten roles for teacher leaders. Teachers as Leaders, 65(1), 74-77

Igwe P. A., Newbery, R., Amoncar, N., White, G.R.T., \& Madichie, N.O. (2018). Keeping It in the Family: Exploring Igbo Ethnic Entrepreneurial Behaviour in Nigeria. International Journal of Entrepreneurial Behavior \& Research DOI:10.1108/IJEBR12-2017-0492, Accepted 24/07/2018

Ikoya, P. O., \& Onoyase, D. (2008). Universal basic education in Nigeria: Availability of infrastructures for effective programme implementation. Educ. Studies, 34: 11-24.

Ivascu, L., Cirjaliu, B. and Draghici, A. (2016). Business Model for the Universityindustry Collaboration in Open Innovation. Procedia Economics and Finance, 39: 674-678 https://doi.org/10.1016/S2212-5671(16)30288-X

Jones, P., Jones, A., Williams-Burnett, N., \& Ratten, V. (2017). Let's get physical: Stories of entrepreneurial activity from sports coaches/instructors. The International Journal of Entrepreneurship and Innovation, 18(4), 219-230.

Kabongo, J. D. \& Okpara, J. O. (2010). Entrepreneurship education in sub- Saharan African universities. International Journal of Entrepreneurial Behavior \& Research, 16 (4), 296-308 https://doi.org/10.1108/13552551011054499

Kincheloe, J. L. (2005). Classroom teaching: An introduction. New York, NY: Peter Lang. USA.

Krecara, I. M., \& Coric, G. (2013). Changes in Entrepreneurial Self-Efficacy since Completion of Entrepreneurial Studies. $2^{\text {nd }}$ Cyprus International Conference on Educational Research, (CY-ICER 2013). Procedia - Social and Behavioral Sciences, 89:74 - 78

Leong, P. A. (2013). Thinking critically: a look at students' critiques of a research article. Higher Education Research \& Development, 32(4), 575-589 DOI: 10.1080/07294360.2012.708322

Marks, M. A., Mathieu, J. E., \& Zaccaro, S.J. (2001). A temporally based framework and taxonomy of team processes. Academy of Management Review, 26(3): 356-76.

Maurer, T. J., Weiss, E. M., and Barbeite, F. G. (2003). A model of involvement in work-related learning and development activity: The effects of individual, situational, motivational \& age variables. Journal of Applied Psychology 88: 707724.

McEwan, D., Ruissen, G. R., Eys, M. A., Zumbo, B. D., \& Beauchamp, M. R. (2017). The Effectiveness of Teamwork Training on Teamwork Behaviors and Team Performance: A Systematic Review and Meta-Analysis of Controlled Interventions. PLoS ONE 12(1): e0169604. https://doi.org/10.1371/journal.pone.0169604

Mero-Jaffe, I. (2011). 'Is that what I said?' Interview Transcript Approval by Participants: An Aspect of Ethics in Qualitative Research. International Journal of Qualitative Methods, 10(3), 231-247

Millar, J. \& Price, M. (2018). Imagining management education: A critique of the contribution of the United Nations PRME to critical reflexivity and rethinking management education. Management Learning 1-17. 
Morris, M.H., Webb, J.W., Fu, J. \& Singhal, S. (2013). A Competency-Based Perspective on Entrepreneurship Education: Conceptual and Empirical Insights. Journal of Small Business Management 51(3), 352-369

Nabi, G., Holden, R., \& Walmsley, A. (2010). From student to entrepreneur: towards a model of graduate entrepreneurial career-making. Journal of Education and Work, 23(5), 389-415.

National Research Council (2010). Preparing teachers: building evidence for sound policy. Washington: The National Academies Press.

Nicol, D.J. and Macfarlane-Dick, D. (2006). Formative assessment and self-regulated learning: a model and seven principles of good feedback practice. Studies in Higher Education, 31(2): 199-218

OECD (2014). TALIS 2013 results: an international perspective on teaching and learning. Organisation for Economic Co-operation and Development. OECD Publishing. http://dx.doi.org/10.1787/9789264196261-en. Accessed: 14/09/2015.

O'Grady, G., Yew, E.H.J., Goh, K.P.L., \& Schmidt, H.G., (2012). One- Day, OneProblem. Springer Verlag. The Netherlands.

Okolie, C.U., Igwe, P.A. \& Elom, E.N. (2018). Improving graduate outcomes for technical colleges in Nigeria. Australian Journal of Career Development, pp. 1-20, doi: $10.1177 / 1038416218772189$.

Oluwatobi, S., Efobi, U., Olurinola, I. \& Alege, P. (2015). Innovation in Africa: why institutions matter? South African Journal of Economics, 83(3), 390-410

Patton, M. Q. (2002). Qualitative research and evaluation methods. 3rd Sage Publications; Thousand Oaks, CA. The United States.

Pittaway, L., \& Cope, J. (2007). Entrepreneurship education a systematic review of the evidence. International Small Business Journal, 25(5), 479-510.

QAA (2018). Enterprise and Entrepreneurship Education: Guidance for UK Higher Education Providers. The UK. January 2018. Accessed 15/06/2018 http://www.qaa.ac.uk/docs/qaas/enhancement-and-development/enterprise-andentrpreneurship-education-2018.pdf?sfvrsn=15f1f981_8

Ratten, V. (2017). Entrepreneurial universities: The role of communities, people and places. Journal of Enterprising Communities: People and Places in the Global Economy, 11(3), 310-315.

Rebmann, K., Schloemer, T., Berding, F., Luttenberger, S., \& Paechter, M. (2015). Preservice teachers' personal epistemic beliefs and the beliefs they assume their pupils have. European Journal of Teacher Education, 38(3), 284-299

Rugimbana, R. (2010). Business strategies for achieving sustainable development in Africa: an introduction to the special issue. African Journal of Economic and Management Studies, 1(2), 121-127

Sharples, J.M., Oliver, S., Oxman, A.D. Mahtani, K.R., Chalmers, I., Collins, K., Austvoll-dahlgren, A. \& Hoffman, T. (2017). Critical thinking: a core skill in education and healthcare. Impact Journal of the Chartered College of Teaching (BMJ 357: J2234) Accessed 10/07/2018. Available at: https://impact.chartered.college/article/sharples-critical-thinking-healthcareeducation/

Shook, C. L., Ketchen, D. J., Cycyota, C. S. and Crockett, D. (2003). Data Analytic Trends and Training in Strategic Management. Strategic Management Journal, 24: $1231-1237$.

Simons, B. B. (2013). What Makes Social Entrepreneurs Different. Harvard Business Review, 01/11/2013. Accessed 04/03/2018, Available at: https://hbr.org/2013/01/what-makes-social-entrepreneur 
Snoek, M. \& Zogla, I. (2009). Teacher education in Europe; main characteristics and developments. In A. Swennen \& M. Klink (Eds.), Becoming a teacher educator: theory and practice for teacher educators (pp. 11-27). Dordrecht: Springer

Stanley, T., \& Marsden, M. (2012). Problem-based learning: Does accounting education need it? Journal of Accounting Education 30(s 3-4), 267-289

Swart, J., \& Harcup, J. (2012). 'If I learn do we learn?': The link between executive coaching and organizational learning. Management Learning, 44 (4), 337-354

United Nations Africa Renewal (2013). Africa's youth: a "ticking time bomb" or an opportunity? UN Department of Public Information. Accessed 04/05/2018 https://www.un.org/africarenewal/magazine/may-2013/africa\%E2\%80\%99s-youth\%E2\%80\%9Cticking-time-bomb\%E2\%80\%9D-or-opportunity

United Nations (2017). Africa's jobless youth cast a shadow over economic growth. Accessed 04/05/2018 https://www.un.org/africarenewal/magazine/special-editionyouth-2017/africas-jobless-youth-cast-shadow-over-economic-growth

UNESCO (2018). Education for Sustainable Development. The United Nations Educational, Scientific and Cultural Organization https://en.unesco.org/themes/education-sustainable-development

UN Principles of Responsible Management Education (2017) Six Principles. Accessed: 12/07/2018, available at: http://www.unprme.org/about-prme/the-six-principles.php

Voogt, J. and Roblin, N. P. (2012). A comparative analysis of international frameworks for 21st-century competencies: Implications for national curriculum policies. Journal of Curriculum Studies 44: 299-321.

Wallace, J., \& Loughran, J. (2012). Science teacher learning. In B. Fraser, K. Tobin, \& C. McRobbie (Eds.), Second international handbook of science education, Vol. 24 (p. 295-306).

Watanabe-Crockett, L. (2018). 12 Strong Strategies for Effectively Teaching Critical Thinking Skills. Accessed 06/07/2018, available at: https://globaldigitalcitizen.org/12-strategies-teaching-critical-thinking-skills

Wengraf, T. (2001). Qualitative Research Interviewing: Biographic Narrative and SemiStructured Methods. London: SAGE.

White, B. (2011) The Role of entrepreneurship and opportunity in Sub-Saharan Africa. The Prosperity Index in Africa. Accessed: 03/04/2017, available at: https://mediaflip.files.wordpress.com/2011/06/20110531-report-the-prosperityindex-in-africa-1.pdf

Zins, C. (2007). Conceptual approaches to defining data, information, and knowledge. Journal of the American Society for Information Science and Technology, 58(4), 479-493. 